\title{
Biochemical and molecular analyses of the C-terminal domain of Era GTPase from Streptococcus pneumoniae
}

\author{
Genshi Zhao, Timothy I. Meier, Robert B. Peery, Patti Matsushima \\ and Paul L. Skatrud
}

Author for correspondence: Genshi Zhao. Tel: +1 317276 2040. Fax: +1 3172761743. e-mail: Zhao_Genshi@Lilly.com

Lilly Research Laboratories, Eli Lilly and Company, Infectious Diseases Research, DC 0438, Indianapolis, IN 462850438, USA

\begin{abstract}
Era, an essential GTPase, is present in many bacteria and Mycoplasma spp. and appears to play a major role in the cell cycle and other cellular processes. To further understand its function, an era gene from Streptococcus pneumoniae was identified and cloned, and a mutant era gene with a deletion of 68 codons from its 3'-terminus was constructed. The truncated Era protein was then purified and characterized, and the ability of the truncated era gene to complement an Escherichia coli mutant strain defective in Era production was examined. Like the full-length Era protein, the truncated Era protein was able to bind and hydrolyse GTP, but its binding activity was increased twofold and its hydrolytic activity was reduced sevenfold when compared with those of the full-length Era protein. Unlike the full-length Era protein, the truncated Era protein lost its ability to bind to the $E$. coli cytoplasmic membrane. The fulllength era gene was able to complement the $E$. coli mutant deficient in Era production when carried on pACYC184, while the truncated era gene failed to do so when carried on PACYC184, pBR322 or pUC18. The cellular amounts of the truncated Era and the full-length Era proteins in E. coli and S. pneumoniae, respectively, were then determined by Western blot analysis. In addition, the minimal amount of the $S$. pneumoniae Era protein needed for complementation of the $E$. coli mutant was also measured. Taken together, these results suggest that the C-terminus of the Era protein might be responsible for the binding of the protein to the cytoplasmic membrane and be essential for function.
\end{abstract}

Keywords: Era, membrane binding, GTPase, growth phase regulation, Streptococcus pneumoniae

\section{INTRODUCTION}

The era gene was first identified in Escherichia coli, and was thought to encode a RAS-like protein (Ahnn et al., 1986). Later, detailed sequence analysis suggested that Era is not a RAS-like protein (Chen et al., 1990). Recently, a human homologue of Era was reported that is distinct from RAS proteins (Britton et al., 1998). Nevertheless, era is present in Gram-positive and Gram-

Abbreviations: Amp, ampicillin; Cam, chloramphenicol; GST, glutathione S-transferase: Tet, tetracycline.

The GenBank accession number for the nucleotide sequence of the Streptococcus: pneumoniae era gene is AF07281. negative bacteria, and Mycoplasma spp. (Ahnn et al., 1986; Fleischmann et al., 1995; Fraser et al., 1995; Kawabata et al., 1997; Zuber et al., 1990, 1997), and is essential for bacterial growth (Gollop \& March, 1991b; Inada et al., 1989; March et al., 1988; Sato et al., 1998; Takiff et al., 1989, 1992). Era proteins are highly conserved among different bacteria and appear to share the same function as evidenced by the fact that era genes from quite diverse bacterial species are able to complement E. coli era mutants (Pillutla et al., 1995; Zuber $e t$ al., 1990, 1997).

The bacterial Era proteins are a unique class of GTPases that bind GTP and GDP and hydrolyse GTP to GDP (March, 1992). The GTP binding and hydrolysis ac- 
tivities of Era appear to be essential for its function since mutations in the era gene of $E$. coli that reduce either or both activities are lethal (Inada et al., 1989; Lerner $e t$ al., 1992, 1995; Lerner \& March, 1991). Point mutations in the C-terminal domain of the E. coli Era protein were isolated and these mutant era genes failed to complement E. coli era mutants (Inada et al., 1989; Lerner et al., 1995; Pillutla et al., 1995). However, the biochemical basis for their failure to complement the E. coli era mutants remains unknown as biochemical characterization of these mutant Era proteins was not described (Lerner et al., 1995; Pillutla et al., 1995).

Genetic studies showed that depletion of the cellular amount of Era inhibited the growth of E. coli cells and caused the cells to elongate (Britton et al., 1997, 1998; Gollop \& March, 1991b; March et al., 1988). Also, the viability of these cells was drastically reduced upon repression of Era production (Gollop \& March, 1991b; Lerner \& March, 1991; March et al., 1988). Under these conditions, cell constriction or septum formation was not observed (Gollop \& March, 1991b), suggesting that Era may play a role in cell cycle control. More recently, genetic studies also demonstrated that a mutation in the E. coli era gene suppressed temperature-sensitive mutations in the genes encoding chromosome replication and partitioning enzymes such as $d n a B$, dnaG, gyr $B, m u k B$, parB and par $C$, but not those of the cell division genes $f t s A, f t s I$ and $f t s Z$ (Britton et al., 1997, 1998). Some of the era mutant cells were found to contain two or four segregated nucleoids (Britton et al., 1997, 1998). These studies suggest that Era plays a role in cell cycle progression at some point, probably after chromosome partitioning but before cytokinesis (Britton et al., 1998).

Immunoelectron microscopic studies localized the $E$. coli Era protein on the internal side of the cytoplasmic membrane and also revealed that the Era protein exists in patches on the membrane (Gollop \& March, 1991a). Later, biochemical studies confirmed that the E. coli Era protein is associated with the cytoplasmic membrane (Lin et al., 1994). This association was GTP- or GDPdependent and could be disrupted by salt treatment ( $\mathrm{Lin}$ et al., 1994). These studies led to the suggestions that potential binding sites exist on the membrane for the Era protein (Lin et al., 1994). However, the significance of this membrane binding activity of Era and the part of Era that is responsible for this association remain unknown.

In this study, we report the biochemical and molecular characterizations of the full-length Era and C-terminally truncated Era $(\Delta \mathrm{Era})$ proteins from Streptococcus pneumoniae. The results of this study show that the $\Delta$ Era protein exhibited a reduced GTP-hydrolysis activity and an increased GTP-binding activity, and failed to bind to the $E$. coli cytoplasmic membrane. The truncated era $(\Delta e r a)$ gene was unable to complement an E. coli mutant defective in Era production (Takiff $e t$ al., 1989, 1992). Together, these results suggest that the Cterminus of the Era protein is essential for the in vivo function of the protein.

\section{METHODS}

Materials. Alkaline-phosphatase-conjugated goat anti-rabbit monoclonal IgG, nitroblue tetrazolium, 5-bromo-4-chloro-3indolyl phosphate, GTP, GDP, ampicillin (Amp), tetracycline (Tet), chloramphenicol (Cam), IPTG and BSA were purchased from Sigma. Prestained molecular mass standards for SDSPAGE (myosin, $208 \mathrm{kDa}$; $\beta$-galactosidase, $116 \mathrm{kDa}$; BSA, $83 \mathrm{kDa}$; ovalbumin, $48.7 \mathrm{kDa}$; carbonic anhydrase, $33.4 \mathrm{kDa}$; soybean trypsin inhibitor, $28 \cdot 2 \mathrm{kDa}$; lysozyme, $20 \cdot 7 \mathrm{kDa}$; and aprotinin, $7 \cdot 6 \mathrm{kDa}$ ) were obtained from Bio-Rad Laboratories. Chelating Sepharose Fast Flow resin and Glutathione Sepharose resin were obtained from Pharmacia LKB Biotechnology. Calf intestinal alkaline phosphatase was obtained from Boehringer Mannheim.

Bacterial strains and culture conditions. The E. coli strains and plasmids used in this study are described in Table $1 . S$. pneumoniae (hex) R6 is an unencapsulated derivative of the Rockefeller University strain R36A that was kindly provided by Dr A. Tomasz (Rockefeller University).

Luria-Bertani (LB) medium capsules were purchased from Bio101. Brain Heart Infusion medium was purchased from Difco. Amp $\left(100 \mu \mathrm{g} \mathrm{ml}^{-1}\right)$, Cam $\left(45 \mu \mathrm{g} \mathrm{ml}^{-1}\right)$, Tet $\left(15 \mu \mathrm{g} \mathrm{ml}^{-1}\right)$ and IPTG were added to media as indicated in each experiment.

Cloning of the era gene from S. pneumoniae (hex) R6. To clone the $S$. pneumoniae era gene, we first searched our M13 S. pneumoniae sequence database (Baltz et al., 1998; Rosteck et al., 1997) using BLAST (Altschul et al., 1990). The era gene was located; however, only a partial sequence was available. By comparing the $S$. pneumoniae DNA sequence to that of the E. coli era gene (Ahnn et al., 1986; Chen et al., 1990) we found that the available sequence was missing both the $5^{\prime}$ - and $3^{\prime}$ terminal regions of the gene. An internal $500 \mathrm{bp}$ fragment from the $S$. pneumoniae era gene was amplified using the primers $5^{\prime}$ CGCGGATCCTCTAGATTCGCGAAGTGGACACTGTTC $3^{\prime}$ and $5^{\prime}$ CGCGGATCCAAACGT'TCTGGATGATCTGTG 3', and used as a probe for Southern blot analysis of $S$. pneumoniae chromosomal DNA (Sambrook et al., 1989). The amplified era probe hybridized to two ClaI fragments with approximate sizes of 1.0 and $3.0 \mathrm{~kb}$ (data not shown). To obtain the missing $3^{\prime}$ - and $5^{\prime}$-terminal sequences of the era gene, we employed inverse PCR technology using ClaI-digested S. pneumoniae genomic DNA as template (DNA was diluted to $\approx 1 \mu \mathrm{g} \mathrm{ml} \mathrm{m}^{-1}$ ) (Innis et al., 1990). Primers were designed based on both sides of the sequences of the internal ClaI site. To amplify the $1.0 \mathrm{~kb}$ ClaI fragment that contained the missing $5^{\prime}$-terminal sequence of the era gene and the $3.0 \mathrm{~kb}$ Clal fragment that contained the missing $3^{\prime}$ end of the gene, we used the following primers: 5' AAAGAACAGTGTCCACTTCGC $3^{\prime}$ and 5' AAGGGGGACGATATGATTATC $3^{\prime}$; and 5' GACAGACAAGGTTCACATCCG 3' and 5' AACCTTCATCCAGATTTTCAC 3', respectively. The PCR reaction mixtures contained $\approx 10 \mathrm{ng}$ ClaI-digested and circularized $S$. pneumoniae chromosomal DNA, $10 \mu \mathrm{l} 10 \times$ PCR buffer containing $\mathrm{MgCl}_{2}$ (Boehringer Mannheim), $8 \mu \mathrm{ldNTPs}(2.5 \mathrm{mM})$, $1 \mu \mathrm{l}$ of each primer ( $50 \mathrm{pmol}), 2.5 \mathrm{U}$ Taq DNA polymerase (Boehringer Mannheim) and $78.5 \mu \mathrm{H}_{2} \mathrm{O}$ (Innis et al., 1990). The following PCR amplification conditions were employed: denaturation at $94^{\circ} \mathrm{C}$ for $30 \mathrm{~s}$, annealing at $55^{\circ} \mathrm{C}$ for $30 \mathrm{~s}$ and polymerization at $72{ }^{\circ} \mathrm{C}$ for $45 \mathrm{~s}$ for the $1 \mathrm{~kb}$ fragment and $90 \mathrm{~s}$ for the $3 \mathrm{~kb}$ fragment for a total of 25 cycles. For each Clal fragment amplified, five PCR reaction products were combined and sequenced directly to derive a consensus sequence. PCR primers were then designed based on the consensus sequence and used to amplify the era gene for cloning into $E$. 
Table 1. Bacterial strains and plasmids

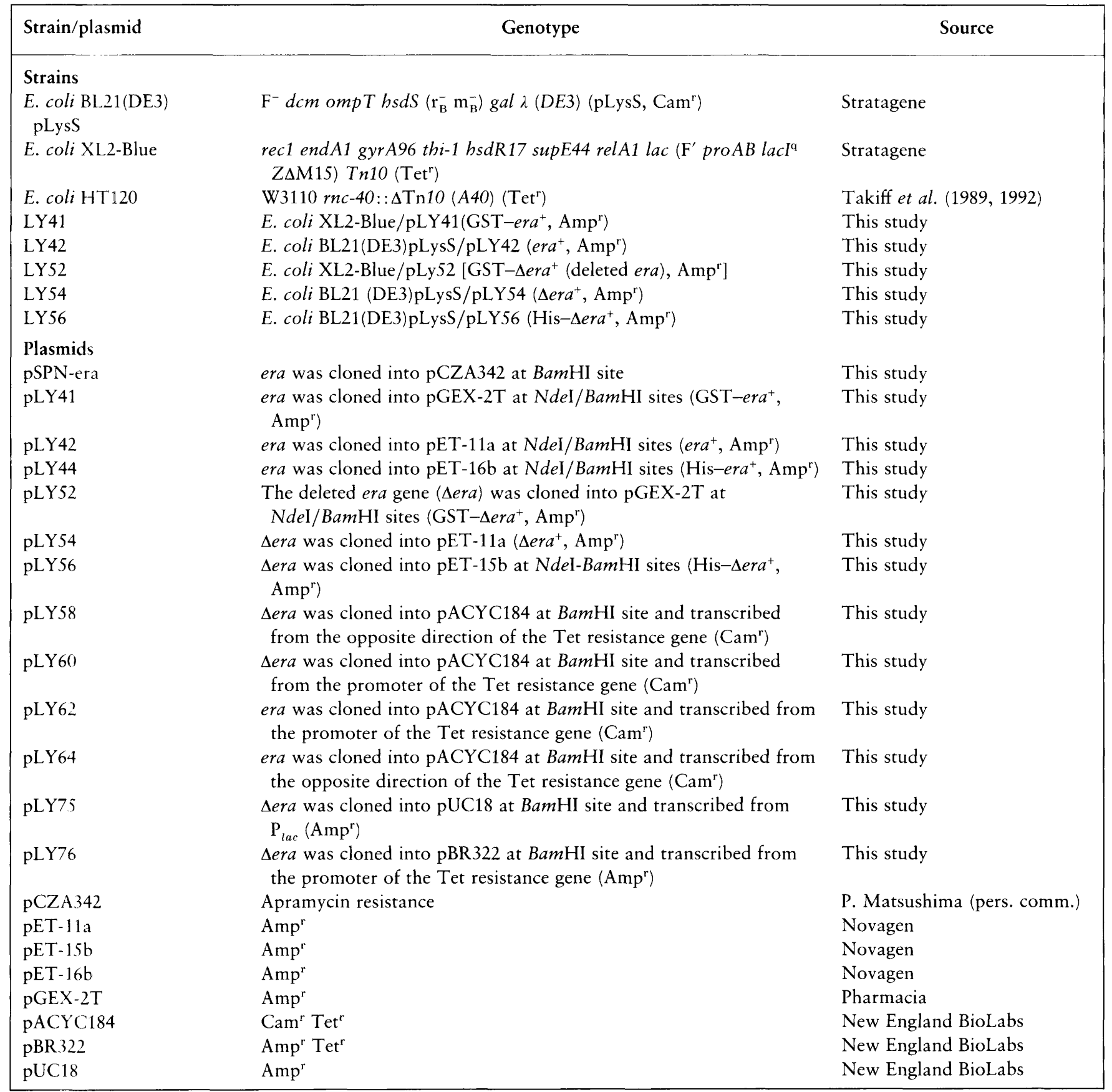

coli expression systems. The $5^{\prime}$ PCR primer $\left(5^{\prime}\right.$ CGCGGATCCTCTAGATTCGCGAAGTGGACACTGTTC 3') was designed at the ATG start codon of era and contains BamHI and $N$ deI sites for cloning purposes. The $3^{\prime} \mathrm{PCR}$ primer $\left(5^{\prime}\right.$ CGCGGATCCAAACGTTCTGGATGATCTGTG 3') was designed at the stop codon of era and contains a BamHI site after the stop codon. Using these primers, era was PCRamplified from $S$. pneumoniae under the following conditions: denaturation at $94^{\circ} \mathrm{C}$ for $30 \mathrm{~s}$, annealing at $55^{\circ} \mathrm{C}$ for $30 \mathrm{~s}$ and polymerization at $72{ }^{\circ} \mathrm{C}$ for $30 \mathrm{~s}$ for 25 cycles. Five PCR reaction products were combined and a portion of the pooled PCR products was digested with BamHI. The Bam HI-digested
PCR fragment was cloned into pCZA342, a low-copy-number plasmid (Baltz et al., 1997), previously digested with BamHI and dephosphorylated with calf intestinal alkaline phosphatase. era from several pCZA342 clones was sequenced and a clone containing the consensus era gene sequence (pSPN-era) was used for constructing expression systems and complementation plasmids. pSPN-era was digested with NdeI and BamHI. The NdeI-BamHI DNA fragment containing era was subcloned into pET-11a and pET-16b (Novagen). The resulting constructs were designated pLY42 and pLY44, respectively (Table 1). pSPN-era was also digested with $B a m \mathrm{HI}$, and the BamHI fragment of era was subcloned into 
pGEX-2T and pACYC184. The resulting constructs were designated pLY52, and pLY62 and pLY64, respectively (Table 1).

To generate a 3'-terminal deletion mutant of era, a 3' PCR primer was designed and used for PCR amplification. The $3^{\prime}$ PCR primer contains DNA sequence complementary to codons 207-213 of the era gene and a BamHI site. A stop codon was also included ( $5^{\prime}$ CGCGGATCCTCAAACTACTGCTACAGAATGCGG $\left.3^{\prime}\right)$. The $5^{\prime}$ PCR primer was the same one described for cloning the full-length era gene into expression vectors. PCR-amplified products were pooled, sequenced and cloned into pCZA342 as described above. The truncated era $(\Delta e r a)$ gene was subsequently cloned into pET$11 \mathrm{a}, \mathrm{pET}-15 \mathrm{~b}$ and pGEX-2T as described above and the resulting constructs were designated pLY54, pLY56 and pLY52, respectively (Table 1 ). The $\Delta$ era gene was also cloned into pACYC184, pBR322 and pUC18 at their BamHI sites, and the resulting constructs were designated pLY58, pLY60, pLY76 and pLY75, respectively (Table 1).

Enzyme assay and kinetics. For determination of $K_{\mathrm{m}}$ and $V_{\max }$ values of Era proteins, reaction mixtures $(300 \mu \mathrm{l}$ each) containing $50 \mathrm{mM}$ Tris $/ \mathrm{HCl}, \mathrm{pH} 7.5,5 \mathrm{mM} \mathrm{MgCl}_{2}$ and $1 \cdot 17 \mu \mathrm{M}$ GST-Era or GST- $\Delta$ Era (GST-truncated Era) were incubated at $23^{\circ} \mathrm{C}$. To initiate the reactions, GTP was added at concentrations of $15-2000 \mu \mathrm{M}$. Aliquots $(100 \mu \mathrm{l}$ each) were removed after incubations for 0.0 and $30 \mathrm{~min}$, and reactions were stopped by adding $5 \mu \mathrm{l} 1 \mathrm{M} \mathrm{HCl}$. Then, $50 \mu \mathrm{l}$ of each aliquot was injected onto a $4.4 \times 250 \mathrm{~mm}$ ODS-AQ HPLC column (YMC) and separated under isocratic conditions (79 $\mathrm{mM}$ potassium phosphate, $\mathrm{pH} 6.0,4 \mathrm{mM}$ tetrabutylammonium hydrogen sulfate, $21 \%$ methanol). Amounts of GDP produced were quantified by comparing its peak areas with those of GDP standards. Since GDP is bound to the protein when purified, the total amount of GDP produced after $30 \mathrm{~min}$ incubation was calculated by subtracting GDP released at the $0.0 \mathrm{~min}$ incubation.

The $k_{\mathrm{d}}$ values of Era proteins were also determined. Briefly, Era proteins were mixed with various amounts of $\left[{ }^{3} \mathrm{H}\right] \mathrm{GTP}$, and the $\left[{ }^{3} \mathrm{H}\right]$ GTP bound to Era proteins was captured using MANP NOB filter plate (Millipore) and quantified by scintillation counting.

Purification of Era proteins. E. coli cells of LY41 [pLY41 (GST-Era)], LY42 [pLY42 (Era)], LY52 [pLY52 (GST- $\Delta$ Era)] and LY 56 [pLY 56 (His- $\Delta$ Era)] were first grown overnight with vigorous shaking at $30^{\circ} \mathrm{C}$ in $\mathrm{LB}$ medium supplemented with $100 \mu \mathrm{g} \mathrm{Amp} \mathrm{ml}{ }^{-1}$. The overnight cultures $(4 \%)$ were inoculated into 1.251 each of fresh LB medium containing Amp. The cultures were induced with $0.8 \mathrm{mM}$ IPTG at $\mathrm{OD}_{600}$ $0.5-0.6$ for $3 \mathrm{~h}$ at $30^{\circ} \mathrm{C}$. Cells were harvested by centrifugation at $4000 \mathrm{~g}$ for $10 \mathrm{~min}$, and washed with $20 \mathrm{mM}$ Tris $/ \mathrm{HCl}, \mathrm{pH}$ $8 \cdot 0$, and $5 \mathrm{mM} \mathrm{MgCl}_{2}$ (buffer A).

For purification of GST- $\Delta$ Era, cells of LY 52 were resuspended in $20 \mathrm{mM}$ Tris/ $\mathrm{HCl}, \mathrm{pH} 7 \cdot 5,140 \mathrm{mM} \mathrm{NaCl}$ and $5 \mathrm{mM} \mathrm{MgCl}_{2}$ (buffer B). The resulting suspension was disrupted by passing twice through a $138 \mathrm{MPa}$ French press cell (Aminco Laboratories) and centrifuged at $180000 \mathrm{~g}$ for $45 \mathrm{~min}$. The supernatant fraction collected was loaded onto a $10 \mathrm{ml}$ Glutathione Sepharose column. The column was washed with $60 \mathrm{ml}$ buffer $B$ and eluted with $10 \mathrm{mM}$ glutathione in buffer B. All fractions were subjected to SDS-PAGE analysis (Laemmli, 1970), and those containing GST $-\Delta$ Era were collected and dialysed using dialysis tubing (molecular mass cut-off, $25 \mathrm{kDa}$; Sigma) in 41 buffer $\mathrm{A}$ at $4{ }^{\circ} \mathrm{C}$ overnight.

For purification of GST-Era, cells of LY41 were disrupted and the resulting suspension was centrifuged as described above. GST-Era was purified as described for GST- $\Delta$ Era.

For purification of His- $\Delta$ Era, cells of LY56 were resuspended in $20 \mathrm{mM}$ Tris/ $\mathrm{HCl}$, pH $8.0,5 \mathrm{mM} \mathrm{MgCl}_{2}$ and $0.5 \mathrm{M} \mathrm{NaCl}$ (buffer C) (Novagen). The resulting suspension was disrupted and centrifuged as described above. The supernatant fraction collected was loaded onto a $10 \mathrm{ml}$ chelating Sepharose column charged with $50 \mathrm{mM} \mathrm{NiCl}{ }_{2}$. The column was washed with $60 \mathrm{ml}$ buffer $\mathrm{C}$ and then $60 \mathrm{mM}$ imidazole in buffer $\mathrm{C}$, and eluted with $0.5 \mathrm{M}$ imidazole in buffer $C$. Fractions containing His $-\Delta$ Era were collected and dialysed as described above except that a $6000-8000 \mathrm{kDa}$ molecular mass cut-off tubing was used.

For purification of the full-length native Era protein, cells of LY42 were disrupted and the resulting suspension was centrifuged as described above. The supernatant fraction collected was loaded onto a Source Q $(30 \mu \mathrm{m}$ diameter $)$ column $(2.6$ by $10 \mathrm{~cm})$ that was previously equilibrated with buffer A. The column was washed with $250 \mathrm{ml}$ buffer $\mathrm{A}$ and eluted with a linear gradient of $0-1000 \mathrm{mM} \mathrm{KCl}$ in buffer $\mathrm{A}$. The presence of Era in fractions was monitored by SDS-PAGE (Laemmli, 1970). The fractions containing Era were pooled and dialysed as described above against 41 (no change) $20 \mathrm{mM}$ potassium phosphate, $\mathrm{pH} 7 \cdot 5$. The dialysed enzyme preparation was applied to a Macro-Prep ceramic hydroxyapatite type I $(80 \mu \mathrm{m}$ diameter $)$ column $(2.6$ by $10 \mathrm{~cm})$ that was equilibrated with $20 \mathrm{mM}$ potassium phosphate, $\mathrm{pH} 7 \cdot 5$. The column was washed with $250 \mathrm{ml}$ of the buffer and eluted with a linear gradient of 20-700 $\mathrm{mM}$ potassium phosphate, $\mathrm{pH} 7 \cdot 5$. The fractions containing Era were pooled and dialysed as described above in buffer A and loaded onto a Heparin (BioRad) column $(2.6$ by $10 \mathrm{~cm})$ that was equilibrated with buffer A. The column was washed with $250 \mathrm{ml}$ buffer A and eluted with a linear gradient of $0-1000 \mathrm{mM} \mathrm{KCl}$ in buffer A. The fractions containing Era were pooled and dialysed as described above in buffer A. The Era protein purified was divided into aliquots and stored as described above.

Antibody preparation and quantitative Western blot analysis of Era in S. pneumoniae. Polyclonal antibodies against SDSdenatured full-length Era protein were prepared (Harlan Bioproducts for Science). Purified Era was denatured by SDS and subjected to SDS-PAGE (10\% gel; Bio-Rad) (Laemmli, 1970 ). Protein bands were visualized by incubating the gel in a solution containing $0.5 \mathrm{M} \mathrm{KCl}$ and $50 \mathrm{mM}$ potassium phosphate ( $\mathrm{pH} \mathrm{7 \cdot 2)}$ and cut out (Zhao \& Winkler, 1995). Each protein band, which contained approximately $100 \mu \mathrm{g}$ Era, was injected into two New Zealand White rabbits.

To compare the expression levels of Era in S. pneumoniae and E. coli, E. coli strains were grown in LB medium as described above and $S$. pneumoniae was grown as described below. A frozen stock of $S$. pneumoniae was inoculated into Brain Heart Infusion broth (Difco) at dilutions of $10^{-6}$ to $10^{-8}$. The cultures were grown at $37^{\circ} \mathrm{C}$ overnight without shaking and harvested at $\mathrm{OD}_{660} 0 \cdot 4$. The cells were washed with $20 \mathrm{mM}$ potassium phosphate, $\mathrm{pH} 7 \cdot 2$, resuspended in buffer $\mathrm{A}$ and $1 \mathrm{M} \mathrm{NaCl}$, disrupted and centrifuged as described above. Supernatant fractions were collected, denatured by SDS (Laemmli, 1970), heated at $100^{\circ} \mathrm{C}$ for $2 \mathrm{~min}$, and subjected to Western blot analysis, which was carried out essentially as described by Zhao \& Winkler (1995) with the following modifications. Transfer was done in $12 \mathrm{mM}$ Tris/ $\mathrm{HCl}, 96 \mathrm{mM}$ glycine and $20 \%$ methanol (Novex) at room temperature (40 V, constant) for $2 \mathrm{~h}$ using a Blot Module (Novex). Membranes were blocked in $1 \times$ PBS (BRL) containing $5 \%$ dry milk at $4{ }^{\circ} \mathrm{C}$ overnight, incubated with primary antibodies 
(1/500 dilutions) and secondary antibodies $(1 / 2000)$ for $2-3 \mathrm{~h}$ at room temperature, and washed three times with $1 \times$ PBS. Protein concentrations were determined using a Bradford assay kit (Bio-Rad) with BSA as a standard (Bradford, 1976).

Determination of association of Era proteins with the membrane. E. coli cells of LY42 and LY54 were first grown in LB medium containing Amp $\left(100 \mu \mathrm{g} \mathrm{ml}^{-1}\right)$ overnight at $35^{\circ} \mathrm{C}$ and the overnight cultures $(3 \%)$ were inoculated into $300 \mathrm{ml}$ LB medium supplemented with Amp. The cultures were grown for $1 \mathrm{~h}$ at $33^{\circ} \mathrm{C}$ and then induced with $1 \mathrm{mM}$ IPTG for $2 \mathrm{~h}$. The cultures were collected and washed as described above. The cells were resuspended in $8 \mathrm{ml}$ buffer $A$ and disrupted as described above. The resulting crude extracts were centrifuged at $12000 \mathrm{~g}$ for $8 \mathrm{~min}$ to remove unbroken cells and potential inclusion bodies. The supernatant fractions collected (4 ml each) were mixed with $1 \mathrm{ml}$ buffer A or $1 \mathrm{ml}$ buffer A containing $5 \mathrm{M} \mathrm{NaCl}$ (final, $1 \mathrm{M}$ ) and centrifuged at $140000 \mathrm{~g}$ for $30 \mathrm{~min}$. The supernatant fractions, designated cytoplasmic fractions, were collected, denatured with SDS, and subjected to SDS-PAGE analysis as described above. The resulting pellets, designated membrane fractions, were washed twice with buffer $A$, resuspended in buffer $A$, and subjected to SDS-PAGE analysis as described above.

$S$. pneumoniae was grown and harvested at $\mathrm{OD}_{660} 0.4$ as described above. Cells were resuspended in $12 \mathrm{ml}$ buffer A, and disrupted as described above. The resulting crude extracts (4 ml each) were mixed with $1 \mathrm{ml}$ buffer $\mathrm{A}$ or $1 \mathrm{ml}$ buffer $\mathrm{A}$ containing $5 \mathrm{M} \mathrm{NaCl}$ (final, $1 \mathrm{M} \mathrm{NaCl}$ ), incubated on ice for $40 \mathrm{~min}$, and centrifuged at $180000 \mathrm{~g}$ for $45 \mathrm{~min}$. Supernatant fractions were collected, denatured by SDS, and subjected to SDS-PAGE analysis as described above. The presence of the Era protein was analysed by Western blotting as described above.

\section{RESULTS}

\section{Identification, cloning and expression of the $S$. pneumoniae era gene}

To clone the $S$. pneumoniae era gene, we first searched our sequence database (Baltz et al., 1998; Rosteck et al., 1997) using the E. coli era sequence as a query in the BLAST program and found that the era gene was not completely sequenced. Both $5^{\prime}$ - and $3^{\prime}$-terminal sequences for era were missing. We then recovered the missing sequences of the gene by inverse PCR and determined its entire sequence. The $S$. pneumoniae era gene, $900 \mathrm{bp}$ long, encodes a protein consisting of 299 amino acids with a predicted molecular mass of 33810 Da. The S. pneumoniae Era protein shares 40, 45 and $95 \%$ identities with those of E. coli, Haemophilus influenzae and Streptococcus mutans, respectively (Ahnn et al., 1986; Chen et al., 1990; Fleischmann et al., 1995; Yamashita et al., 1993). The S. pneumoniae Era protein contains all conserved motifs for GTP binding at the $\mathrm{N}$-terminal part of the protein and also all conserved motifs of boxes A-D identified by Zuber et al. (1997), which are located at the C-terminus of the protein (Zuber et al., 1997). The S. pneumoniae era gene complements an E. coli mutant strain defective in Era production (see below). We also constructed a truncated era ( $\Delta e r a)$ gene by removing 68 codons from its 3'terminus. As a result, the $\Delta$ Era protein does not contain

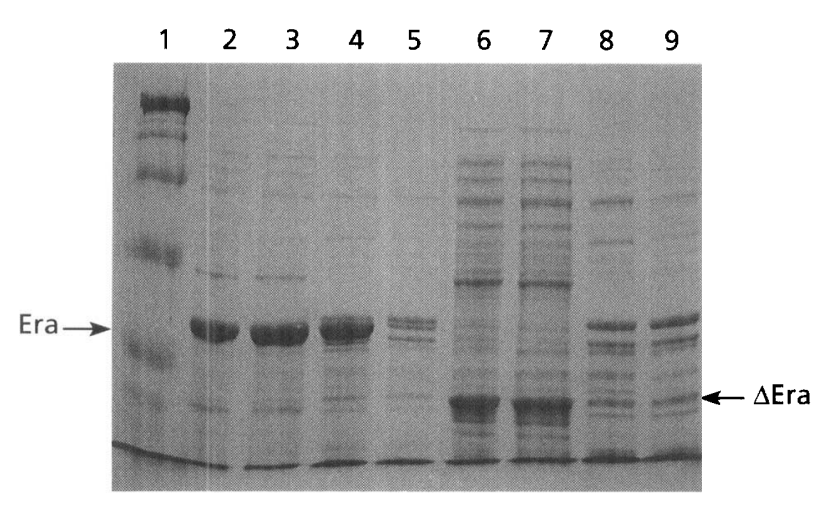

Fig. 1. SDS-PAGE analysis of the association of the $S$. pneumoniae Era and $\Delta$ Era proteins with the $E$. coli cytoplasmic membrane. Cells were grown, collected and disrupted as described in Methods. The resulting crude extracts were centrifuged at $12000 \mathrm{~g}$ for $8 \mathrm{~min}$ to remove unbroken cells and potential inclusion bodies. The supernatant fractions collected were mixed with buffer $A(20 \mathrm{mM}$ Tris/ $/ \mathrm{HCl}, \mathrm{pH} 8.0,5 \mathrm{mM} \mathrm{MgCl}$ ) or buffer $A$ plus $1 \mathrm{M} \mathrm{NaCl}$, and centrifuged (Methods). The supernatant fractions collected, designated cytoplasmic preparations, were denatured and subjected to SDS-PAGE analysis (Methods). The pellet fractions collected, designated membrane preparations, were washed twice with and resuspended in buffer $A$, and denatured and subjected to SDSPAGE analysis (Methods). Lanes: 1, prestained molecular mass markers (from top to bottom: myosin, $208 \mathrm{kDa} ; \beta$-galactosidase, $116 \mathrm{kDa}$; $\mathrm{BSA}, \quad 83 \mathrm{kDa}$; ovalbumin, $48.7 \mathrm{kDa}$; carbonic anhydrase, $33.4 \mathrm{kDa}$; soybean trypsin inhibitor, $28.2 \mathrm{kDa}$; lysozyme, $20.7 \mathrm{kDa}$; and aprotinin, $7.6 \mathrm{kDa}) ; 2$ and 3 ( $6 \mu \mathrm{l} \mathrm{each}$ ), the cytoplasmic preparation of LY42 (era-pET-11a) which was treated with buffer $A$ and $1 \mathrm{M} \mathrm{NaCl}$ in buffer $A$, respectively; 4 and $5(6 \mu \mathrm{l}$ each), the membrane preparation of LY42 which was treated with buffer $A$ and $1 \mathrm{M} \mathrm{NaCl}$ in buffer $A$, respectively; 6 and $7(6 \mu$ leach), the cytoplasmic preparation of LY54 ( $\Delta$ era-pET-11a) which was treated with buffer A and $1 \mathrm{M}$ $\mathrm{NaCl}$ in buffer A, respectively; 8 and $9(6 \mu \mathrm{l}$ each), the membrane preparation of LY54 which was treated with buffer $A$ and $1 \mathrm{M} \mathrm{NaCl}$ in buffer $A$, respectively.

the last two conserved motifs of boxes C-D (Zuber et al., 1997). The full-length and $\Delta e r a$ genes were cloned into $E$. coli expression vectors and expressed in native form, in GST-fusion form or in His-fusion form (Table 1).

\section{Purification and characterization of $\Delta$ Era proteins}

To understand the role of the C-terminal portion of Era, we purified GST $-\Delta$ Era and His $-\Delta$ Era to homogeneity (Fig. 1; and data not shown). Our first attempt to purify $\Delta$ Era from LY 54 using the three-step column chromatography procedure (Methods) failed to yield a homogeneous protein preparation $(\approx 50 \%$ pure $)$ due to its relatively low level of expression in E. coli (Fig. 1). Therefore, we characterized the purified GST $-\Delta$ Era and His $-\Delta$ Era proteins for their ability to utilize GTP under the conditions described (Methods). Like the full-length native Era proteins (Ahnn et al., 1986; Chen et al., 1990; Lerner et al., 1992; March et al., 1988; Wu et al., 1995), GST $-\Delta$ Era and His $-\Delta$ Era proteins were able to bind and hydrolyse GTP. The apparent $K_{\mathrm{m}}$ value determined for 
Table 2. Complementation of $E$. coli HT120 by era and $\Delta$ era

E. coli HT120 was transformed with different plasmids and selected on LB plates containing appropriate antibiotics. The LB plates were incubated at $30^{\circ} \mathrm{C}$ for $24 \mathrm{~h}$ and examined for growth. +++ , Large colonies; + , small colonies; - , no growth.

\begin{tabular}{|c|c|c|c|}
\hline \multirow[t]{2}{*}{ Complementing plasmid } & \multirow[t]{2}{*}{ Orientation of era and $\Delta e r a^{*}$} & \multicolumn{2}{|c|}{ Growth of transformants } \\
\hline & & + Tet & - Tet \\
\hline pLY62 (era-pACYC184) & The same as $\mathrm{P}_{\text {tet }}$ & +++ & +++ \\
\hline pLY64(era-pACYC184) & $\begin{array}{l}\text { Opposite to } \mathrm{P}_{t e t} \text {, but the } \\
\text { same as } \mathrm{P}_{c a m}\end{array}$ & +++ & + \\
\hline pLY60 (Aera-pACYC184) & The same as $\mathrm{P}_{t e t}$ & +++ & - \\
\hline pLY58 (Aera-pACYC184) & $\begin{array}{l}\text { Opposite to } \mathrm{P}_{t e t} \text {, but the } \\
\text { same as } \mathrm{P}_{c a m}\end{array}$ & +++ & - \\
\hline pLY76 (Aera-pBR322) & The same as $\mathrm{P}_{t e t}$ & +++ & - \\
\hline pLY75 (Aera-pUC18)† & The same as $\mathrm{P}_{l a c}$ & +++ & - \\
\hline pLY41 (era-pGEX-2T) & The same as $\mathrm{P}_{l a c}$ & $++t$ & $++t$ \\
\hline pACYC184 & & +++ & - \\
\hline pBR322 & & +++ & - \\
\hline pGEX-2T & & +++ & - \\
\hline pUC18† & & +++ & - \\
\hline
\end{tabular}

" $\mathrm{P}_{t e t}$, the Tet resistance gene promoter of pACYC184 and pBR322; $\mathrm{P}_{\text {cam }}$, the Cam resistance gene promoter of $\mathrm{pACYC184}$; and $\mathrm{P}_{l a c}$, the lac promoter of pUC18.

† The E. coli HT120 transformants carrying pLY75 and pUC18 were selected on LB plates containing $0 \cdot 0,0 \cdot 2$ or $1.5 \mathrm{mM}$ IPTG, incubated, and examined as described in Methods.

GST- $\Delta$ Era was $232 \mu \mathrm{M}$ and the apparent $V_{\max }$ value obtained for the enzyme was $28 \mathrm{mmol} \mathrm{min} \mathrm{mol}^{-1} \mathrm{~mol}^{-1}$. Similar results were obtained for His $-\Delta$ Era (data not shown). The $k_{\mathrm{d}}$ value for GST- $\Delta$ Era was determined to be $2 \cdot 1 \mu \mathrm{M}$. The kinetic parameters $\left(K_{\mathrm{m}}, V_{\max }\right.$ and $\left.k_{\mathrm{d}}\right)$ determined for the full-length Era were $430 \mu \mathrm{M}$, $200 \mathrm{mmol} \mathrm{min}{ }^{-1} \mathrm{~mol}^{-1}$ and $4 \cdot 2 \mu \mathrm{M}$, respectively. Therefore, the removal of the C-terminal part of Era resulted in a twofold increase in its affinity for GTP and a sevenfold decrease in its GTP-hydrolysis activity.

\section{Association of Era proteins with the E. coli and S. pneumoniae cytoplasmic membranes}

The Era proteins of E. coli and S. mutans have been shown to be associated with the cytoplasmic membrane (Gollop \& March, 1991a; Lin et al., 1994; Wu et al., 1995). To examine whether the S. pneumoniae Era protein is also associated with the cytoplasmic membrane, we performed Western blot analysis of the crude extracts of $S$. pneumoniae. We found that there was about twofold more Era protein detected in the crude extract that was treated with $1 \mathrm{M} \mathrm{NaCl}$ than in the untreated sample (data not shown). This finding suggests that like other Era proteins, the S. pneumoniae Era protein is also associated with the cytoplasmic membrane and this association can be disrupted by salt treatment.

We also showed that the full-length native Era protein of $S$. pneumoniae, when expressed in E. coli, was clearly associated with the cytoplasmic membrane (Fig. 1, lane 4), and that this association can be disrupted by salt treatment (Fig. 1, lane 5). Consistent with this finding, there was twofold more Era protein detected in the cytoplasmic preparation that was treated with $1 \mathrm{M}$ $\mathrm{NaCl}$ than in the untreated sample (Fig. 1, lanes 2 and 3). Similarly, the full-length GST-Era (pLY41) and His-Era (pLY44) proteins were also found to be associated with the $E$. coli cytoplasmic membrane when expressed in $E$. coli (data not shown).

We also analysed the truncated Era $(\Delta E$ Era) proteins for their possible association with the $E$. coli cytoplasmic membrane. However, we found no evidence that the $\Delta$ Era proteins were associated with the E. coli cytoplasmic membrane when expressed directly (pLY54) or in a GST-fusion ( $\mathrm{pLY} 52$ ) or His-fusion (pLY56) form in $E$. coli, and the salt treatment of the crude extracts of LY52, LY54 and LY56 had no effect at all on its possible association with the cytoplasmic membrane (Fig. 1, lanes 6-9; and data not shown). Thus, the removal of the C-terminal part of Era resulted in the failure of the $\Delta$ Era protein to associate with the cytoplasmic membrane.

\section{Complementation of an E. coli mutant strain defective in Era production}

To further analyse the function of the C-terminal part of Era in vivo, we tested whether the full-length era and $\Delta$ era genes complement the $E$. coli mutant strain 
(a)

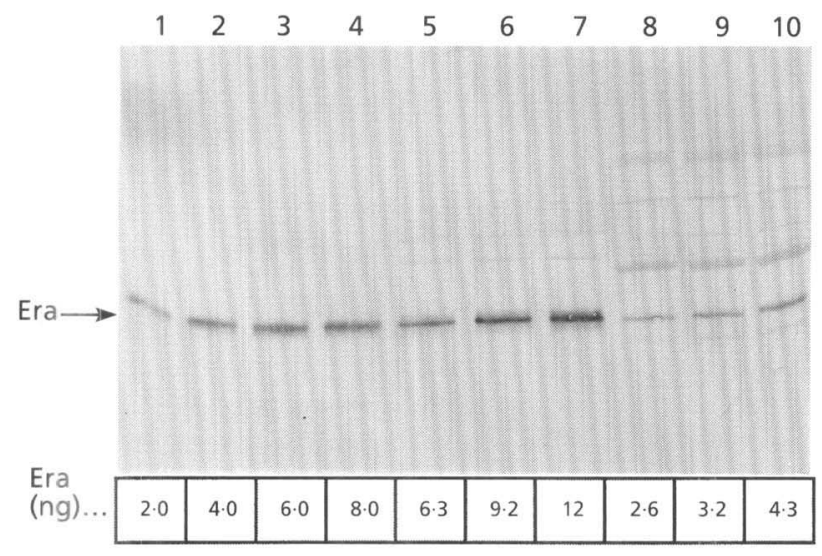

(b)

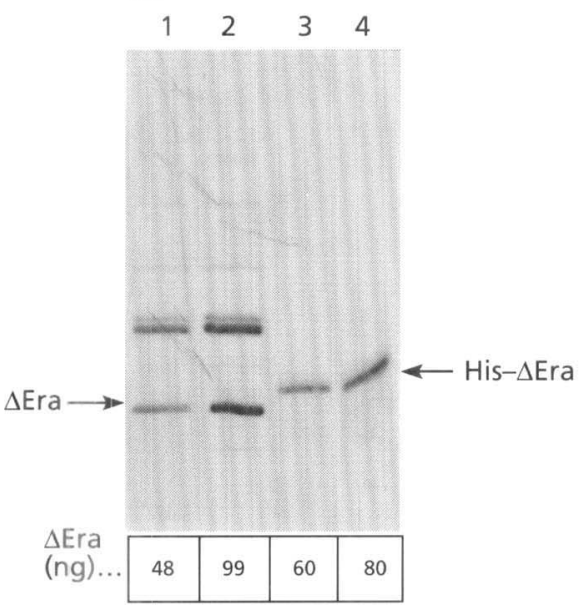

Fig. 2. Immunodetection of cellular amounts of the Era and $\Delta$ Era proteins produced in S. pneumoniae and E. coli HT120, respectively, with antibodies prepared against the $S$. pneumoniae Era protein. S. pneumoniae was grown, collected and disrupted as described in Methods. E. coli HT120 harbouring pUC18 or pLY75 was grown in LB and induced with $1.5 \mathrm{mM}$ IPTG upon inoculation with overnight cultures. Cells were collected and disrupted as described in Methods. The resulting crude extracts were centrifuged, and supernatant fractions were collected and denatured as described in Methods. (a) Lanes: 1-4, 2, 4, 6 and 8 ng purified full-length Era protein, respectively; $5-7,10,15$ and $20 \mu \mathrm{g}$ of the supernatant fraction of $S$. pneumoniae R6, respectively; 8-10, 10, 15 and $20 \mu \mathrm{g}$ of the supernatant fraction of $E$. coli HT120(pLY64) (erapACYC184, opposite to $P_{\text {tet }}$ ), respectively. (b) Lanes: 1 and 2, 3.75 and $7.5 \mu \mathrm{g}$ of the supernatant fraction of $E$. coli HT120(pLY75) (Dera-pUC18), respectively; 3 and 4, 60 and $80 \mathrm{ng}$ purified His- $\Delta$ Era protein, respectively.

defective in Era production, HT120 (Takiff et al., 1989, 1992). HT120 contains a mini-Tn10 insertion upstream of the $r n c$ gene which forms part of an operon with its downstream gene, era (Takiff et al., 1989, 1992). The mini-Tn10 carries two divergent Tet-inducible promoters (Takiff et al., 1989, 1992). In the absence of Tet, HT120 could not grow on LB plates because the mini-Tn10 insertion is downstream polar to era, which in turn blocks the transcription of the era gene. Thus, growth of HT120 is Tet-dependent. Like era genes from several other organisms (Pillutla et al., 1995; Zuber et al., 1990, 1997), the full-length era gene of S. pneumoniae complemented the E. coli mutant HT120 when cloned into pACYC184 (pLY62 and pLY64) in either orientation with respect to the direction of transcription of the Tet resistance gene because the HT120 transformants were able to grow on LB plates without supplementation of Tet (Table 2). When HT120 was transformed with pLY62 (e.g. era was cloned into pACYC184 in the same orientation as the transcription of the plasmid Tet resistance gene), the resulting transformants grew equally well on LB plates supplemented with or without Tet (Table 2), showing that pLY62 was able to fully complement HT120. Interestingly, when HT120 was transformed with pLY64 (e.g. era was cloned into pACYC184 in the opposite orientation with respect to the transcription of the Tet resistance gene, but in the same orientation as the transcription of the distant Cam resistance gene), the resulting transformants grew very slowly on LB plates without the supplementation of Tet (Table 2). The colony size of these transformants [HT120(pLY64)] was only $1 / 4-1 / 3$ of those growing on LB plates supplemented with Tet after $24 \mathrm{~h}$ incubation at $30^{\circ} \mathrm{C}$ (Table 2). This observation suggests that the amount of Era protein expressed from pLY64 is limiting to the cell growth. Therefore, the amount of Era produced under these conditions was probably close to the minimal level of Era that is required for complementation of the E. coli mutant HT120. Our Western blot analysis showed that the minimal level of Era required for growth is $2.6 \mathrm{ng}$ per $10 \mu \mathrm{g}$ or $0.26 \mathrm{ng}$ per $\mu \mathrm{g}$ total cellular protein (Fig. 2a, lane 8).

When the era gene was cloned into pGEX-2T (pLY41), the resulting GST-era fusion gene also complemented the E. coli HT120 mutant (Table 2), even in the absence of IPTG, suggesting that the GST-Era fusion protein was expressed and functional in the cell.

Unlike the full-length era gene, the $\Delta e r a$ gene of $S$. pneumoniae was unable to complement the E. coli mutant HT120 when carried on pACYC184, pBR322 or pUC18 (Table 2). The failure of the $\Delta$ era gene to complement the E. coli mutant suggested two possibilities. First, the C-terminal part of the Era protein is essential for function. Second, the $\Delta e r a$ gene was not expressed or expressed at a very low level. To test these possibilities, we carried out Western blot analysis of the E. coli mutant HT120 carrying the $\Delta e r a$ gene on the plasmids. The expression levels of the $\Delta e r a$ gene were barely detectable in HT120 harbouring pLY58 and pLY60 (Aera-pACYC184) and pLY76 (Aera-pBR322) (data not shown). Thus, the $\Delta e r a$ gene was poorly expressed when carried on these plasmids. However, when HT120 was transformed with pLY75 (AerapUC18) and induced with $1.5 \mathrm{mM}$ IPTG, the amount of $\Delta$ Era produced in HT120 was $48 \mathrm{ng}$ per $3.75 \mu$ g or 12.8 ng per $\mu$ g total cellular protein (Fig. 2b, lane 1). This is 20 -fold higher than that of Era in S. pneumoniae since the amount of Era present in S. pneumoniae was estimated to be 6.3 ng per $10 \mu \mathrm{g}$ or $0.63 \mathrm{ng}$ per $\mu \mathrm{g}$ total 
cellular protein (Fig. 2a, lane 5). Thus, the failure of the $\Delta e r a$ gene to complement the E. coli mutant deficient in Era production was not due to its poor expression; rather it suggests that the C-terminal domain of the Era protein is probably essential for function.

\section{DISCUSSION}

In this study, we found that removal of the C-terminal portion of the $S$. pneumoniae Era protein resulted in a twofold increase in its GTP-binding activity, a sevenfold decrease in its GTP-hydrolysis activity, and the loss of its ability to associate with the E. coli cytoplasmic membrane. In addition, the removal of the 3 -terminal part of the era gene also led to the inability of the sera gene to complement the $E$. coli mutant strain defective in Era production. The failure of the sera gene to complement the E. coli mutant HT120 was not due to its poor expression or insoluble protein formation. When the E. coli mutant HT120 was transformed with pLY75 (Aera-pUC18) and induced with 0.2 and $1.5 \mathrm{mM}$ IPTG, the amounts of the Era protein produced were estimated to be 6.8 (data not shown) and $12.5 \mathrm{ng}$ per $\mu \mathrm{g}$ total protein, respectively, which are at least $10-$ and 20 fold higher than that of the Era protein present in $S$. pneumoniae. Since the molecular mass of the $\Delta$ Era protein is $26 \mathrm{kDa}$, which is $24 \%$ smaller than that of the full-length Era protein, the molar concentrations of $\Delta$ Era produced in E. coli HT120 should be 13- and 26fold higher than that of Era in S. pneumoniae. The amounts of the Era protein detected in HT120(pLY75) represent all soluble protein retained in the crude extract after centrifugation at $180000 \mathrm{~g}$ for $45 \mathrm{~min}$. We also established that the minimal amount of the $S$. pneumoniae Era needed for complementation of the $E$. coli mutant HT120 was 0.26 ng per $\mu$ g total cellular protein, which is twofold lower than that of Era present in $S$. pneumoniae. The minimal amount of Era determined was probably an overestimate since the antibodies prepared against the $S$. pneumoniae Era protein appear able to recognize the E. coli Era protein (Fig. 2b, lanes 1 and 2). Therefore, the amounts of $\Delta$ Era produced in HT120(pLY75) are at least 26- and 52-fold higher than the minimal amount of Era needed for complementation. Since the $\Delta$ Era protein exhibits a sevenfold reduction in its GTP-hydrolysis activity but a twofold increase in its GTP-binding activity, the amount of the $\Delta$ Era protein produced in HT120(pLY75) should make up the total activity that is needed for complementation. Clearly, these results suggest that the removal of the Cterminus of the Era protein renders the Era protein unable to function in vivo. Therefore, the C-terminal domain of the Era protein is essential for the function of the protein.

Several studies have suggested that the C-terminal domain of Era proteins might be important for function. However, in many cases a complete study was not presented. Point mutations in the C-terminal domain of the E. coli Era protein were isolated and these mutant era genes failed to complement an E. coli era mutant
(Pillutla et al., 1995), but biochemical characterization of these mutant Era proteins was not given (Pillutla et al., 1995). A temperature-sensitive mutation in the GTPase domain of a truncated E. coli Era protein has been reported and the biochemical characterization of this mutant Era protein was also described (Inada et al., 1989). This era mutant, however, requires the Cterminal deletion of the Era protein for its temperature sensitivity (Inada et al., 1989). Cold-sensitive point mutations in the C-terminal domain of the E. coli Era protein have also been reported, but biochemical characterization of these mutant proteins was not presented (Lerner et al., 1995). Thus, our study represents the first complete biochemical and genetic analyses of the Cterminal domain of an Era protein.

The era gene was first discovered in E. coli by the similarity of its derived amino acid sequence to the RAS proteins of Saccharomyces cerevisiae (Ahnn et al., 1986). Later, further detailed sequence analysis of the RAS proteins and the E. coli Era protein did not appear to support the contention that the E. coli Era protein is a RAS-like protein (Chen et al., 1990). Recently, a human homologue of Era was reported which exhibits $30 \%$ identity to the E. coli Era protein (Britton et al., 1998). The human homologue is distinct from RAS proteins (Britton et al., 1998). Nevertheless, some of the nucleotide-binding motifs of the yeast RAS, human Ras, human Era and bacterial Era proteins seem to be conserved during evolution (Ahnn et al., 1986; Bourne et al., 1991; Britton et al., 1998; Chen et al., 1990; March, 1992; Pillutla et al., 1995; Zuber et al., 1990, 1997), but the C-terminal part of the Era proteins (from residues 201 to the end) appears to represent a domain that is unique to and conserved among the bacterial Era proteins (Pillutla et al., 1995; Zuber et al., 1990, 1997).

Unlike RAS proteins that are attached to the cytoplasmic membrane through acylation of palmitic acid (Barbacid, 1987), the bacterial Era proteins are found to be associated with the cytoplasmic membrane (Gollop \& March, 1991a; Lin et al., 1994; Wu et al., 1995). The significance of this membrane association has not yet been assessed. Our studies show that the $\Delta$ Era protein of $S$. pneumoniae can no longer bind to the cytoplasmic membrane and also the sera gene is unable to complement the E. coli mutant deficient in Era. These observations suggest that the C-terminal domain of the Era protein might be responsible for its attachment to the membrane, and this attachment (or association) of the Era protein to the membrane appears to be essential for the biological function of the protein. Thus, this study supports the hypothesis that Era is involved in a GTPase-receptor-coupled membrane-signalling pathway (Lin et al., 1994).

The minimal amount of $S$. pneumoniae Era protein required for complementation of the $E$. coli mutant HT120 is $0.26 \mathrm{ng}$ per $\mu \mathrm{g}$ or $0.026 \%$ of total protein. The cellular amount of Era protein in S. pneumoniae is about $0.63 \mathrm{ng}$ per $\mu \mathrm{g}$ or $0.063 \%$ of total protein. The E. coli Era protein was estimated to be $10 \mathrm{ng}$ per $1.5 \times 10^{8}$ cells or 
$\approx 0.022 \%$ of total protein since the mean soluble protein of an E. coli $\mathrm{K}-12$ cell was determined to be $3.3 \times 10^{-7} \mu \mathrm{g}$ (Gollop \& March, 1991a; Zhao \& Winkler, 1995). Thus, the cellular amounts of Era proteins are similar in E. coli and S. pneumoniae. These results have several implications. First, the amount of Era protein produced in vivo is probably very close to what is needed for cell growth, and may be tightly modulated. Second, the Era protein of $S$. pneumoniae appears able to function very efficiently in $E$. coli because overexpression of the protein was not required. Finally, all Era proteins examined seem to share the same function regardless of their phylogenetic histories.

\section{ACKNOWLEDGEMENTS}

We thank D. L. Court, A. Tomasz and M. E. Winkler for bacterial strains used in this study. We thank S. R. Jaskunas for his support, stimulating discussions and advice, and T. R. Parr and the members of our Streptococcus pneumoniae Genomics Group for their support. We also thank D. L. Court, J. M. Colacino, T. I. Nicas, M. C. Smith and H. Watson for critical review of the manuscript.

\section{REFERENCES}

Ahnn, J., March, P. E., Takiff, H. E. \& Inouye, M. (1986). A GTPbinding protein of Escherichia coli has homology to yeast RAS proteins. Proc Natl Acad Sci USA 83, 8849-8853.

Altschul, S. F., Gish, W., Miller, W., Myers, E. W. \& Lipman, D. J. (1990). Basic local alignment search tool. J Mol Biol 215, 403-410.

Baltz, R. H., Matsushima, P., Peery, R. B. \& 10 other authors (1997). Use of genomics and insertional mutagenesis to identify targets for antibiotic development in Streptococcus pneumoniae. Abstracts of the 37th Interscience Conference on Antimicrobial Agents and Chemotherapy (Ontario, Canada), 391(S-46).

Baltz, R. H., Norris, F. H., Matsushima, P. \& 13 other authors (1998). DNA sequence sampling of the Streptococcus pneumoniae genome to identify novel targets for antibiotic development. Microb Drug Resist 4, 1-9.

Barbacid, M. (1987). Ras genes. Annu Rev Biochem 56, 779-827. Bourne, H. R., Sanders, D. A. \& McCormick, F. (1991). The GTPase superfamily: conserved structure and molecular mechanism. Nature 349, 117-127.

Bradford, M. M. (1976). A rapid and sensitive method for the quantitation of microgram quantities of protein utilizing the principle of protein-dye binding. Anal Biochem 72, 248-254.

Britton, R. A., Powell, B. S., Court, D. L. \& Lupski, J. R. (1997). Characterization of mutations affecting the Escherichia coli essential GTPase Era that suppress two temperature-sensitive dnaG alleles. J Bacteriol 179, 4575-4582.

Britton, R. A., Powell, B. S., Dasgupta, S., Sun, Q., Margolin, W., Lupski, J. R. \& Court, D. L. (1998). Cell cycle arrest in Era GTPase mutants: a potential growth rate-regulated checkpoint in Escherichia coli. Mol Microbiol 27, 739-750.

Chen, S.-M., Takiff, H. E., Barber, A. H., Dubois, G. C., Bardwell, J. C. A. \& Court, D. L. (1990). Expression and characterization of RNaselII and Era proteins: products of the $r n c$ operon of Escherichix coli. J Biol Chem 265, 2888-2895.

Fleischmann, R. D., Adams, M. D., White, O. \& 37 other authors (1995). Whole-genome random sequencing and assembly of Haemophilus influenzae Rd. Science 269, 496-512.

Fraser, M., Gocayne, J. D., White, O. \& 26 other authors (1995).
The minimal gene complement of Mycoplasma genitalium. Science 270, 397-403.

Gollop, N. \& March, P. E. (1991a). Localization of the membrane binding sites of Era in Escherichia coli. Res Microbiol 142, 301-307.

Gollop, N. \& March, P. E. (1991b). A GTP-binding protein (Era) has an essential role in growth rate and cell cycle control in Escherichia coli. J Bacteriol 173, 2265-2270.

Inada, T., Kawakami, K., Chen, S., Takiff, H. E., Court, D. L. \& Nakamura, Y. (1989). Temperature-sensitive lethal mutant of Era, a G protein in Escherichia coli. J Bacteriol 171, 5017-5024.

Innis, M. A., Gelfand, D. H., Sninsky, J. J. \& White, T. J. (1990). PCR Protocols: a Guide to Methods and Applications. New York: Academic Press.

Kawabata, S., Terao, Y., Andoh, T. \& Hamada, S. (1997). Nucleotide sequence and molecular characterization of a gene encoding GTP-binding protein from Streptococcus gordonii. FEMS Microbiol Lett 156, 211-216.

Laemmli, U. K. (1970). Cleavage of structural proteins during the assembly of the head of bacteriophage T4. Nature 227, 680-685.

Lerner, C. G. \& March, P. E. (1991). Pleiotropic changes resulting from depletion of Era, an essential GTP-binding protein in Escherichia coli. Mol Microbiol 5, 951-957.

Lerner, C. G., Sood, P., Ahnn, J. \& Inouye, M. (1992). Coldsensitive growth and decreased GTP-hydrolytic activity from substitution of Pro17 for Val in Era, an essential Escherichia coli GTPase. FEMS Microbiol Lett 95, 137-142.

Lerner, C. G., Gulati, P. S. \& Inouye, M. (1995). Cold-sensitive conditional mutations in Era, an essential Escherichia coli GTPase, isolated by localized random polymerase chain reaction mutagenesis. FEMS Microbiol Lett 126, 291-298.

Lin, Y. P., Sharer, J. D. \& March, P. E. (1994). GTPase-dependent signaling in bacteria: characterization of a membrane-binding site for Era in Escherichia coli. J Bacteriol 176, 44-49.

March, P. E. (1992). Membrane associated GTPases in bacteria. Mol Microbiol 6, 1253-1257.

March, P. E., Lerner, C. G., Ahnn, J., Cui, X. \& Inouye, M. (1988). The Escherichia coli Ras-like protein (Era) has GTPase activity and is essential for cell growth. Oncogene 2, 539-544.

Pillutla, C. R., Sharer, J. D., Gulati, P. S., Wu, E., Yamashita, Y., Lerner, C. G., Inouye, M. \& March, P. E. (1995). Cross-species complementation of the indispensable Escherichia coli era gene highlights amino acid regions essential for activity. J Bacteriol 177, 2194-2196.

Rosteck, P. R., Jr, Norris, F. H., Matsushima, P. \& 13 other authors (1997). Streptococcus pneumoniae genome sequence sampling. In Developments in Industrial Microbiology, pp. 13-20. Edited by R. H. Baltz, G. D. Hageman \& P. L. Skatrud. Washington, DC: Society for Industrial Microbiology.

Sambrook, J., Fritsch, E. F. \& Maniatis, T. (1989). Molecular Cloning: a Laboratory Manual, 2nd edn. Cold Spring Harbor, NY: Cold Spring Harbor Laboratory.

Sato, T., Wu, J. \& Kuramitsu, H. (1998). The $s g p$ gene modulates stress responses of Streptococcus mutans: utilization of an antisense RNA strategy to investigate essential gene functions. FEMS Microbiol Lett 159, 241-245.

Takiff, H. E., Chen, S.-M. \& Court, D. L. (1989). Genetic analysis of the rnc operon of Escherichia coli. J Bacteriol 171, 2581-2590.

Takiff, H. E., Baker, T., Copeland, T., Chen, S.-M. \& Court, D. L. (1992). Locating essential Escherichia coli genes by using miniTn10 transposon: the $p d x J$ operon. J Bacteriol 174, 1544-1553. 
Wu, J., Cho, M.-I. \& Kuramitsu, H. K. (1995). Expression, purification, and characterization of a novel G protein, SGP, from Streptococcus mutans. Infect Immun 63, 2516-2521.

Yamashita, Y., Takehara, T. \& Huramitsu, H. K. (1993). Molecular characterization of a Streptococcus mutans mutant altered in environmental stress responses. J Bacteriol 175, 6220-6228.

Zhao, G. \& Winkler, M. E. (1995). Kinetic limitation and cellular amount of pyridoxine (pyridoxamine) 5 '-phosphate oxidase of Escherichia coli K-12. J Bacteriol 177, 883-891.

Zuber, M., Hoover, T. A., Powell, B. S. \& Court, D. L. (1990).
Analysis of the rnc locus of Coxiella burnetii. Mol Microbiol 14, 291-300.

Zuber, M., Hoover, T. A., Dertzbaugh, M. T. \& Court, D. L. (1997). A Francisella tularensis DNA clone complements Escherichia coli defective for the production of Era, an essential Ras-like GTPbinding protein. Gene 189, 31-34.

Received 29 October 1998; revised 7 December 1998; accepted 4 January 1999. 